\title{
BENEDEK Tibor
}

\section{Partnerközpontú cselekvési ütemterv kidolgozása a szakképzésben megjelenő feladatok megvalósításához}

\section{Bevezetés - Problémafelvetés}

„A hazai oktatási rendszert - és benne a szakképzés területét is - alapjaiban szükséges újragondolni. Mivel egy gépezet egészéről van szó, nem elég, ha a fogaskerék egy elemét próbáljuk javítgatni, tisztogatni. Fontosnak tartjuk, hogy a szakképzés reformjának az egyik legfontosabb vezérlőelve a gazdaság fejlődése legyen. Ennek egyik alapvető mozgatórugója a magas színvonalon képzett szakemberek jelenléte. Olyan feltétel ez, amely elengedhetetlen a hazai vállalkozások versenyképességéhez." " mondta Bihall Tamás, a Magyar Kereskedelmi és Iparkamara alelnöke, 2013-ban.

Azóta eltelt kettô év és szemtanúi lehetünk az oktatási rendszer, azon belül a szakképzés átalakításának is. Az átalakítással kapcsolatos feladatok mindig többlet terhet rónak az oktatási intézményekre, valamint felmerülnek olyan problémák, melyekre előre nem gondolt egyik fél sem.

A szakképzés átalakításának több problematikus pontja is lehet, mint például a duális képzés megvalósulása; a szakképzési centrumok kialakítása; a szakképző iskolákat érintő fenntartó váltás; a kamarai garanciavállalás a szakképző iskolák és a gazdálkodó szervezetek felé, mely a tanulószerződések számának növelését tűzte ki célul. Ezek a feladatok akkor tudnak optimálisan megvalósulni, ha az oktatási intézmény, a kamara, a gazdálkodó szervezetek között egy dinamikusan múködô partneri kapcsolat van.

Mindhárom fél számára fontos, hogy gördülékenyen tudjanak együtt dolgozni az állandó változások ellenére.

Az évfolyamdolgozatban szeretném felvázolni azokat a lépéseket, melyeket az oktatási intézmény, jelen esetben a Wattay Szakképző Iskola tehet a megfelelő kapcsolatrendszer kialakításában.

\section{A kapcsolatrendszer szervezettségének fejlesztése}

Mit is tekinthetünk külső környezetnek? Hogyan viszonyulhatnak a külső partnerekhez az oktatási- nevelési intézmények? Ezekre a kérdésekre adja meg a választ dr. Kapa Mátyás, Nevelési-oktatási intézmény és környezete I. címú könyvében: „Ebben az összefüggésben a nevelési-oktatási intézmény környezetét az azt körülvevő, azzal kölcsönhatásban lévő külvilág alkotja: minden, ami nem az intézmény, de hatással van rá. A nevelési-oktatási intézmény szerves részét képezi egy, a társadalom közös ügyeit intéző tágabb rendszernek, feladatellátó struktúrának, a nevelési-oktatási intézmény és a közszolgáltatásokat ellátó egyéb intézmények között funkcionális interakció áll fenn. $(\ldots)^{2}$ Az utolsóként említett partneri környezet, az intézményesített kapcsolatok rendszere szintén alapvetően befolyásolja a nevelési-oktatási intézmény napi múködését, sőt stratégiáját is.

C: \Users \Benedek Tibor $\backslash$ Desktop $\backslash$ kereslet_kínálat.png

\footnotetext{
${ }^{1}$ Marton József (2013): Interjú Bihall Tamással, a Magyar Kereskedelmi és Iparkamara alelnökével. Szak- és felnőttképzés, A Nemzeti Munkaügyi Hivatal folyóirata, 2. évfolyam, 2013. 1. szám. (18-23. p.)

${ }^{2}$ Dr. Kapa Mátyás: Nevelési-oktatási intézmény és környezete I., BME, Budapest, 2015, 4.old.
} 
A téma részletes kifejtése előtt érdemes áttekintenünk azt a környezetet, amelyben mindhárom szereplő részt vesz. Ez a intézményi környezet nem más, mint a munkaerôpiac, ahol az oktatási intézmény a képzett szakembereket biztosítja a gazdálkodó szervezetek részére. Ebben a folyamatban a Kereskedelmi és Iparkamara is részt vesz, hiszen ő egyszerre tartja a kapcsolatot az iskolákkal és a vállalkozókkal is. Ezt a kapcsolódást szemlélteti az alábbi ábra, kifejezve az adott folyamatban e három partner teljes mértékű egymásrautaltságát.

1. ábra Az oktatási intézmény, a gazdálkodó szervezet és a kamara egymásrautaltsága a munkaerő-piaci egyensúly fenntartásában ${ }^{3}$

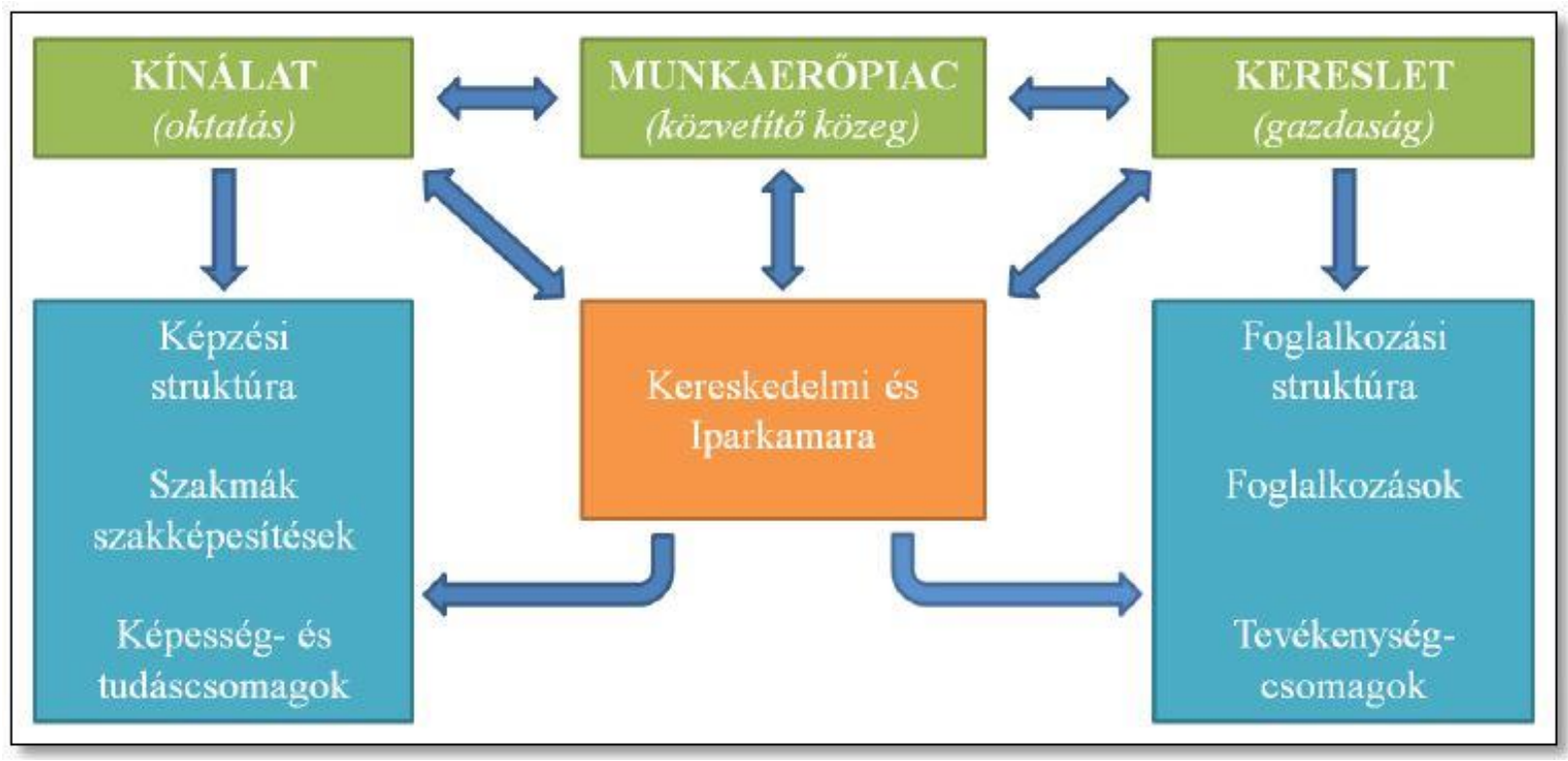

A szakképző iskolákban kialakított képzési struktúra, az oktatott szakképesítések, biztosítják a tanulók számára azon képességek, elméleti - gyakorlati tudáscsomagok elsajátítását, melyre a gazdálkodó szervezetnek szüksége van. A gazdálkodó szervezet az iskola képzési struktúrájából emeli át a tanulót a saját foglalkozási rendszerébe, s a megszerzett tudást az adott foglalkozás tevékenységeiben kamatoztatja. A kamara mintegy szabályozó és összhangteremtő szervezetként vesz részt ebben a folyamatban. Gondolhatunk ebben az esetben a kamara által kidolgozott kerettantervekre, a szintvizsgák megszervezésére, a vállalatok akkreditációjára, ezt követően a kamarai garanciavállalásra és az információ megfelelő áramlására. E háromtényezős kapcsolatrendszer minősége teljes mértékben meghatározza a munkaerőpiac kereslet-kínálat egyensúlyát. Ebben az esetben a kapcsolatrendszert elsősorban a szakképző iskola szempontjából vizsgáljuk, hiszen „az oktatás célrendszere hidat képez a társadalom értékrendje, szükségletrendszere és az iskolai praxis között. ezek a közösen elfogadott értékek képezik a közoktatási rendszer múködését meghatározó nemzeti tantervek cél és követelményrendszerét"4 - írja Dr. Lükő István Oktatástan című művében.

A továbbiakban a tanév során felmerülő feladatok vonatkozásában kerül ismertetésre a három partner közötti kapcsolatrendszer folyamata. Időbeli tervezés szempontjából a legcélszerűbb iskolai félévekre bontani a tervezés nagyobb szakaszait.

\footnotetext{
3 Az ábra dr Vartmann György - A változó szakképzés előadásának anyaga alapján készült. Az előadás elhangzott Balatonszemesen 2015. október 02-án, a BME közoktatásvezetői és pedagógus szakvizsga továbbképzési tréningjén ${ }^{4}$ Dr. Lükő István: Oktatástan - Az oktatás elmélete és gyakorlata, Nyugat-magyarországi Egyetem, Sopron, 2003. 55.p.
} 
Az elsö félév során felmerïló feladatok

A megfelelő kapcsolatrendszer elemeként az intézmény részéről szükséges kijelölni a külső vállalkozókkal, a kamarával együttmúködő kapcsolattartót, nagyobb tanuló létszám esetén a kapcsolattartókat.

A szeptemberi iskolakezdés során a külső partnerek felé az első feladatok között jelenik meg a tanév iskolai munkarendjének megküldése, valamint az aktuális órarend továbbítása a gazdálkodószervezetek részére.

Szintén idetartozik az összefüggő szakmai gyakorlat teljesítési igazolásaink összegyűjtése a gyakorlati képzőhelyekről, hiszen az összefüggő szakmai gyakorlat teljesítése a magasabb évfolyamba való továbblépés feltétele.

Célszerủ az első két hét után leegyeztetni a tanulói névsorokat az iskolatitkárságon, a tanulók tanulószerződéseit leellenőrizni, hiszen előfordulhat, hogy a nyár folyamán valakinek megszűnt a tanulószerződése és más gazdálkodó szervezettel létesített szerződést. A tanulószerződés megszűnésének a másik lehetősége, hogy a tanuló évfolyamismétlésre lesz kötelezett, s így a júniusban megkötött tanulószerződést meg kell szüntetni. Ezzel a feladattal függ szorosan össze a gazdálkodó szervezetek adatbázisának frissítése, aktualizálása. A szakképző iskolának jelentési kötelezettsége is van a kamara felé az aktuális tanmúhelyes vagy tanulószerződéses tanulók számáról a szakképzési törvény alapján. ${ }^{5}$

A tanulócsoportok kialakítása és ellenőrzése után a frissített adatbázis alapján a gazdálkodó szervezet számára célzottan kell elküldeni az adott szakképesítések helyi tanterveit és szakmai és vizsgakövetelményeit. Ehhez kacsolódik, hogy az intézménynek a honlapon a szintvizsgafeladatokat is nyilvánosságra kell hozni, ez egyrészt a tanulók, másrészt pedig a vállalati tanműhelyben lévő diákok szempontjából fontos, hogy célirányosan tudjanak készülni a szintvizsgára.

Amennyiben a gazdálkodó szervezetek adatbázisa alapján új gyakorlati képzőhely került az iskolával kapcsolatba, akkor a kamarai tanácsadó és az iskola képviselóje (gyakorlati oktatásvezetô) meglátogatja az új képzőhelyet személyes kapcsolatteremtés céljából. A képzőhely akkreditációja ekkorra már megtörtént, így ez a látogatás nem ellenőrzô, hanem mentoráló, támogató szemléletû.

Az oktatási intézmény, a gazdálkodó szervezetek és a kamara között az alapvető kapcsolattartás a gyakorlati oktatásvezető feladata, aki munkáját a szakképzési igazgatóhelyettes irányításával, vele együttmúködésben végzi. Az intézményen belül ebbe a kapcsolatrendszerbe az osztályfőnökök is helyet kapnak, mégpedig abban a vonatkozásban, hogy a gazdálkodó szervezetektől havonta érkező gyakorlati érdemjegyeket és magatartás, szorgalom osztályzatokat ők rögzítik az elektronikus naplóba. Fontos, hogy az iskolában elért eredményekről a gazdálkodó szervezetek is megfelelő tájékoztatást kapjanak, ezt a feladatot szintén az osztályfőnökök valósíthatják meg negyedévenkénti jelentés formájában a cégek kapcsolattartói felé.

Fontos megemlíteni, hogy a gazdálkodó szervezetek és a kamara felé jelezni kell azt is, hogyha a tanulószerződéssel rendelkező tanuló ellen fegyelmi eljárást készülnek indítani és az idevonatkozó jogszabályok szerint az érdekelt felet a fegyelmi tárgyalásra szükséges meghívni. „A fegyelmi eljárás megindításáról a tanulót, a kiskorú tanuló szülőjét, a gyakorlati képzés során elkövetett fegyelmi vétség esetén - ha a fegyelmi vétséggel érintett gyakorlati képzés folytatója nem az iskola - a gyakorlati képzés folytatóját (a továbbiakban: gazdálkodó szervezet), tanulószerződés esetén a területileg illetékes gazdasági kamarát értesíteni kell a tanuló terhére rótt kötelességszegés

5 2011. évi CLXXXVII. törvény a szakképzésről 46.S(1) bekezdés, 87.』 (3) bekezdés 
megjelölésével. Az értesítésben fel kell tüntetni a fegyelmi tárgyalás időpontját és helyét, azzal a tájékoztatással, hogy a tárgyalást akkor is meg lehet tartani, ha a gazdálkodó szervezet vagy a területileg illetékes gazdasági kamara képviselője szabályszerū értesítés ellenére, valamint a tanuló, a szülő ismételt szabályszerű meghívás ellenére nem jelenik meg. Az értesítést oly módon kell kiküldeni, hogy azt a tanuló, a szülő külön-külön a tárgyalás előtt legalább nyolc nappal megkapja. ${ }^{6}$

Az oktatási intézmény, a kamara, a gazdálkodószervezetek kapcsolatát és megjelenését a külső környezet felé nagymértékben megjelenítheti egy Pályaválasztási Kiállitás, ahol mindhárom partner képviselteti magát. Ez abból a szempontból is fontos, hogy a pályaválasztás előtt álló tanulók láthatják, hogy a Wattay Szakképző Iskolában megszerzett tudás után van további perspektíva a jelenlévő képzőhelyeken. A kamara pedig ismertetheti a tanulókkal az őket megillető juttatásokat, a szakmatanulásban rejlő lehetőségeket. Amennyiben a kiállítás üzemlátogatással kerül közös megrendezésre, akkor a rendezvény még sikeresebb lehet és motiválhatja a tanulókat a szakmatanulásra.

November hónapban az oktatási intézmény a kamara példája alapján minden gazdálkodó szervezet részére egy referatúra levélben tudja elküldeni a megvalósult feladatokról szóló tájékoztatást, az adott tanévben a tanév rendjén túlmenően felmerült egyéb feladatokról és rendezvényekről tud tájékoztatatást adni, valamint a következő tanévre vonatkozó beiskolázási keretszámokat tudja ismertetni, így a gazdálkodó szervezetek a humánerőforrásaikkal jobban tudnak gazdálkodni. Ebben az időszakban szokott megvalósulni az SZKTV-re történő jelentkeztetés is, melyben mindhárom szervezet részt vesz. A kamara által üzemeltetett Szakmasztár honlapon az oktatási intézmény rögzíti a versenyzők adatait, majd erről a felületről kinyomtatja a jelentkezési lapot, melyet az iskola és a gazdálkodó szervezet egyaránt hivatalos aláírással lát el, ezek papír alapon történő postázása után a kamara regisztrálja a versenyzőket.

Szintén november hónapban kell egy előzetes adatlapot kitölteni a kamara részére, mely tartalmazza a szintvizsgázók létszámát, a szakmák megnevezését, a felelősöket, és a vizsga helyszíneket, időpontokat.

Látszólag kicsiny, azonban mégsem elhanyagolható gesztus az iskolai marketing részéről a külső partner cégeknek, a kamarának, a szakképzési tanácsadóknak egy papíralapú karácsonyi üdvözlőlap küldése, mellyel az oktatási intézmény a partner szervezeteket megerősíti abban a tudatban, hogy az iskola számára fontos a velük való kapcsolat, s a jövőben továbbra is együtt kívánnak velük múködni.

A januári hónap egyszerre több feladatot is ró az oktatási intézményre. Egyrészt az első félévet kell lezárni és a félévi eredményekről a gazdálkodó szervezeteket célszerű értesíteni, többek között azért is, mert akárcsak tanév elején ebben az esetben is a tanulószerződéses tanulóknak a juttatása tanulmányi átlageredménytől függően változhat. A szakképzési igazgatóhelyettes ekkorra már összeállította a májusi -júniusi vizsgaidôszak ütemtervét. Itt az is elképzelhetô, hogy a gyakorlati vizsgarészek nem az oktatási intézményben kerülnek megtartásra, hanem kiszervezett vizsga lesz valamelyik gyakorlati képzőnél. Természetesen ebben az esetben már akár december hónap érdemes egyeztetni a tervezett vizsgahelyszín kapcsolattartójával. A végleges ütemtervet célszerű elküldeni a vállalkozóknak, hiszen ebből látják, hogy tanulóiknak mennyi idejük van még a felkészülésre, valamint tájékozódhatnak az utolsó vizsga időpontjáról is, hiszen ebben az esetben a gazdálkodó szervezetnek az adott nappal (sikeres szakmai vizsga esetén) ki kell jelenteni a társadalombiztosítási rendszerból a tanulót.

6 20/2012. (VIII. 31.) EMMI rendelet a nevelési-oktatási intézmények múködéséről és köznevelési intézmények névhasználatáról 56.§ (2) bekezdés; vö.: 2011. évi CLXXXVII. törvény a szakképzésről 58.S(6) bekezdés 


\section{A második félév során felmerüló feladatok.}

A második félév elején szükséges a kilencedikes tanulókat tájékoztatni a tanulószerződések megkötésének rendjéről és a főbb határidőkről. Ebben a folyamatban mindhárom szervezet részt vesz. Az iskola gyakorlati képzőhelyet ajánl a tanulóknak, a gazdálkodó szervezetek fogadják a tanulókat, a kamara pedig a folyamat végén hitelesíti a tanulószerződéseket. Az ágazati középiskolai képzésben ez az időpont alkalmas arra, hogy a nyári időszakban megvalósuló összefüggő szakmai gyakorlathoz szükséges gyakorlati képzőhelyeket felkeressék és velük együttmúködési megállapodást kössenek, ekkor a három szervezetnek ismét együtt kell dolgoznia.

Február végén, március elején történik meg a szakmai vizsgák bejelentése, melyre az NSZFH jelöli az elnököt, a kamara pedig a vizsgabizottsági tagokat adja. Ebben az időszakban kezdődhetnek meg a gyakorlati szintvizsgák, melyeket a kamara szervez az oktatási intézményekkel együttmúködve. A kapcsolattartás, a bejelentés módja ebben az esetben speciális, hiszen a jelentések az ISZIIR felületén történnek.

Április végén (a szintvizsgák után, a szakmai vizsgák megkezdése előtt) valósulhat meg egy szakképzési fórum összehívása, melyen mindhárom szervezet részt vesz. A szakmai fórumon ismertetésre kerülnek a várható változások, a következő tanévben megvalósításra kerülő képzések, a kamarai garanciavállalás során felmerült feladatok egyeztetése, majd a fórum további részében egy-egy szakképesítés külön szekcióban tudja átbeszélni az őket érintő kérdéseket. Ekkor kerülhet sor a jövőben történő üzemlátogatások egyeztetésére, az egyes gazdálkodók tanulói szükségleteinek meghatározására.

A májusi - júniusi vizsgaidőszak során az oktatási intézmény a gyakorlati vizsgákat kiszervezheti a gazdálkodó szervezetekhez, különösen nagyobb létszámú vizsgacsoportok esetén, ugyanakkor a kilencedik évfolyamos tanulók ebben az időszakban véglegesítik tanulószerződéseiket, melyeket a kamara érvényesít, hogy az adott szorgalmi időszak végétől (általában június közepe) a tanulók a külső gyakorlati képzőhelyeken kezdhessék meg tanulmányaikat; ez az időszak mindhárom fél számára különösen megterhelő.

A nyári időszak során lehetőség adódik arra, hogy a kamara és az iskola képviselője felkeresse a gyakorlati képzőhelyeket és tapasztalatokat szerezzen az egyes cégek infrastrukturális, oktatási hátterérôl. A látogatás ebben az esetben is természetesen támogató, segítő szándékkal történik.

A tanév utolsó hónapjában fejeződik be az új tanév előkészítése. A javítóvizsgák megvalósítása és az órarendi tervezet elkészülése után célszerủ a javítóvizsga eredményeit megküldeni az érintett cégeknek, az órarendi tervezet megtekintése során a külső képzőhely esetleg jelezheti az iskolának, hogy másmilyen osztásban kéri a gyakorlati csoportok órarendjét a folyamatos termelés, és kiegyensúlyozott oktatás érdekében.

\section{A partnerközpontú cselekvési ütemterv bemutatása}

Az alábbiakban kerül bemutatásra az a cselekvési ütemterv, mely a három partner, gazdálkodó szervezet, kamara, szakképző iskola kölcsönös együttmúködésén alapszik és részleteiben tartalmazza az elvégzendő feladatok időpontjait, partnereit, a kapcsolattartáshoz szükséges módszereket, valamint a felelősöket. 
Partnerközpontú cselekvési ütemterv a szakképzési feladatok megvalósítására

\section{Időpont}

Szeptember

Október

November

December
Feladat

Kapcsolattartók kijelölése az oktatási intézmény részéről

A tanév iskolai munkarendjének, órarendjének (tervezet) megküldése a gazdálkodó szervezetek részére Az összefüggő szakmai gyakorlat igazolásaink összegyűjtése

Tanulói névsorok

egyeztetése,

tanulószerződések

egyeztetése

Gyakorlati képzőhelyek adatbázisának frissítése

Tanulószerződések listájának megküldése a kamarai tanácsadónak A gazdálkodó szervezetek részére a helyi tantervek, az SZVK-k megküldése

Új gyakorlati képzőhelyek meglátogatása

Pályaválasztási Kiállítás megszervezése, megrendezése

Referatúra levél megküldése a

SZKTV-re történô jelentkezés

Szintvizsgázók létszámának megküldése a kamara részére

Első negyedévi eredmények megküldése a gazdálkodó szervezeteknek

Szakmai gyakorlati vizsga külső helyszínének

egyeztetése

PR- karácsonyi üdvözlőlapok megküldése a gazdálkodó

szervezeteknek, kamarának

\section{Partnerek}

Az iskola pedagógusai

A gazdálkodó

szervezetek képviselői

A gazdálkodó

szervezetek képviselői

Az iskola pedagógusai

Gazdálkodó szervezetek

Kereskedelmi és

Iparkamara szakképzési tanácsadója

Gazdálkodó szervezetek

Gazdálkodó

szervezetek,

Kereskedelmi és

Iparkamara szakképzési

tanácsadója

Gazdálkodó

szervezetek,

Kereskedelmi és

Iparkamara szakképzési

tanácsadója

Gazdálkodó szervezetek

Gazdálkodó

szervezetek,

Kereskedelmi és

Iparkamara

Kereskedelmi és

Iparkamara

Gazdálkodó szervezetek E-mail

Gazdálkodó szervezetek

E-mail

Gazdálkodó

szervezetek,

Nyomtatott levél

Módszer

Személyes megbeszélés, írásosos megbízás

E-mail

E-mail, telefon, levél

E-mail, személyes megbeszélés

E-mail, telefon

E-mail

E-mail

Személyes megbeszélés

E-mail, telefon, személyes megbeszélés

E-mail

Online felület

Kereskedelmi és Iparkamara

\section{Felelősök}

Igazgató, igazgatóhelyettes, gyakorlati oktatásvezetô

Gyakorlati oktatásvezető

Gyakorlati oktatásvezető, osztályfőnökök Igazgatóhelyettes, gyakorlati oktatásvezető, osztályfőnökök, iskolatitkár Kapcsolattartók, iskolatitkár

Gyakorlati oktatásvezető, iskolatitkár

Gyakorlati oktatásvezető, kapcsolattartók Gyakorlati oktatásvezető, kapcsolattartó

Igazgató, igazgatóhelyettes, gyakorlati oktatásvezető

Gyakorlati oktatásvezető, kapcsolattartók Igazgatóhelyettes, gyakorlati oktatásvezető szaktanárok Igazgatóhelyettes, gyakorlati oktatásvezető Osztályfőnökök, kapcsolattartók

Igazgatóhelyettes, gyakorlati oktatásvezető Igazgató, iskolatitkár, kapcsolattartók 
Január

Február

Március

Szakmai vizsgák

Július

Augusztus

Első félévi eredmények megküldése a gazdálkodó

szervezeteknek

Szakmai vizsgaütemterv

megküldése a gazdálkodó

szervezeteknek

Kilencedikes tanulók

tajékoztatása a

tanulószerződések

megkötésének módjáról

Ágazati szakközépiskolai képzésben résztvevők

tájékoztatása az

együttmúködési

megállapodások

megkötésének módjáról

A tanulószerződések,

együttműködési

megállapodások

előkészítése

Szakmai vizsgák

bejelentése

Gyakorlati szintvizsgák

megrendezése

Április

Szakképzési fórum

összehívása

Május - június

Tanulószerződések, együttmúködési megállapodások véglegesítése

Gazdálkodó szervezetek meglátogatása az iskola részéről

A következő tanév előkészítése

\section{Gazdálkodó szervezetek E-mail \\ Gazdálkodó szervezetek E-mail}

Az intézmény

kilencedikes tanulói

Az ágazati

szakközépiskolai

képzésben résztvevő

tanulók

Gazdálkodó

szervezetek,

Kereskedelmi és

Iparkamara

Kereskedelmi és

Iparkamara

Kereskedelmi és

Iparkamara

Gazdálkodó

szervezetek,

Kereskedelmi és

Iparkamara

Gazdálkodó

szervezetek,

Kereskedelmi és

Iparkamara

Gazdálkodó

szervezetek,

Kereskedelmi és

Iparkamara

Gazdálkodó

szervezetek,

Kereskedelmi és

Iparkamara

Gazdálkodó

szervezetek,

Kereskedelmi és

Iparkamara

E-mail, telefon
Személyes beszélgetés

Osztályfőnökök, kapcsolattartók

Igazgatóhelyettes, gyakorlati oktatásvezető

Igazgatóhelyettes, gyakorlati oktatásvezető

Személyes beszélgetés

Igazgatóhelyettes, gyakorlati oktatásvezető

Online felület

Online felület

E-mail, személyes beszélgetés, fórum

E-mail, telefon, személyes beszélgetés

E-mail, telefon, személyes beszélgetés

E-mail, telefon, személyes beszélgetés

Igazgatóhelyettes, gyakorlati oktatásvezető, kapcsolattartók Igazgatóhelyettes, gyakorlati oktatásvezető, osztályfőnökök, iskolatitkár Igazgatóhelyettes, gyakorlati oktatásvezető Igazgató, igazgatóhelyettes, gyakorlati oktatásvezető Igazgatóhelyettes, gyakorlati oktatásvezető

Igazgatóhelyettes, gyakorlati oktatásvezető, osztályfőnökök, iskolatitkár Igazgatóhelyettes, gyakorlati oktatásvezető

E-mail, telefon

Igazgatóhelyettes, gyakorlati oktatásvezető 


\section{Összegzö befejezés}

Az évfolyamdolgozat bevezetésében említésre került, hogy a szakképzésben megjelenő „feladatok akkor tudnak optimálisan megvalósulni, ha az oktatási intézmény, a kamara, a gazdálkodó szervezetek között egy dinamikusan múködő partneri kapcsolat van.”

A fentiekben felvázolt eljárásrend alkalmazása során, az adott intézmény környezeti elemeinek vizsgálatával, a jövőben látható változások átgondolásával, a külső partnerek véleményének, javaslatinak elfogadásával és az oktatási intézmény sajátosságainak figyelembevételével az elkészült cselekvési terv sikeresen adaptálható lesz más szakképző iskolák részére is. Így az iskola, a kamara valamint a gazdálkodó szervezetek közötti kapcsolattartás elősegítheti a szakképzés eredményesebb múködését.

\section{Felhasznált irodalom}

- Dr. Kapa Mátyás: Nevelési-oktatási intézmény és környezete I., BME, Budapest, 2015.

- Dr. Kapa Mátyás: Nevelési-oktatási intézmény és környezete II., BME, Budapest, 2015.

- Marton József (2013): Interjú Bihall Tamással, a Magyar Kereskedelmi és Iparkamara alelnökével. Szak- és felnőttképzés, A Nemzeti Munkaügyi Hivatal folyóirata, 2. évfolyam, 2013. 1. szám.

- Dr. Vartmann György: Szakképzés-igazgatás, BME, Budapest, 2015.

\section{Felhasznált jogszabályok}

- 2011. évi CXC. törvény a nemzeti köznevelésről

- 2011. évi CLXXXVII. törvény a szakképzésről

- 20/2012. (VIII. 31.) EMMI rendelet a nevelési-oktatási intézmények múködésérôl és a köznevelési intézmények névhasználatáról 